\title{
Experimental investigation of actual situation of using and accounting of recovered energy of regenerative braking mode at the DC traction system
}

\author{
Oleh Bondar , Dmytro Ustymenko, Olena Kurylenko, Mykhailo Kedria, Oksana Karzova, Roman Krasnov, and Oleksii \\ Baliichuk \\ Dnipro National University of Railway Transport named after Academician V. Lazaryan, Department of Electrical Engineering and \\ Electromechanics, Lazaryana Str. 2, room 125, 49000, Dnipro, Ukraine
}

\begin{abstract}
This paper deals with the problems of enhancement of registration and distribution of electric energy which can be obtained from DC electric locomotives by the regenerative braking. According to theoretical researches, it is possible to return approximately $8-12 \%$ of electric energy which is consumed for electric traction by using of a regenerative braking mode. However in recent years for electric traction networks of JSC "Ukrainian Railways", this index doesn't exceed 2.6\%. So we consider that the regenerative braking is one of the most prospective ways for energy saving in electric railway transport. Results of the experimental researches which were executed on DC traction substations and VL11M6 electric locomotives are described in this paper. Instantaneous values of voltage and current in different modes have been obtained. The electric energy balance for experimental zone has been performed. Also the ways of distribution and consumption of energy of regenerative braking mode have been analyzed. On this basis of the executed investigations, recommendations about providing of supercapacitor energy storage system for Ukrainian railways are proposed.
\end{abstract}

\section{Introduction}

Railway transport is one of the largest and stable consumers of electric energy in Ukraine. Annual consumption of electric energy for traction by the Ukrainian railways exceeds $3800 \mathrm{MWh}$. At the same time the actual average tariff for the active electric power for traction annually grows so the problems of electric power efficiency at the railway transport are relevant for Ukraine. We consider that the regenerative braking is one of the most prospective ways for energy saving in electric railway transport. According to theoretical researches, it is possible to return approximately $8-12 \%$ of electric energy which is consumed for electric traction by using of a regenerative braking mode. However in recent years for electric traction networks of JSC "Ukrainian Railways" (UZ), this index doesn't exceed $2.6 \%$ [1].

Improvement of this situation can be reached by use of energy storage system (ESS) with supercapacitors (SC) [2-4]. Therefore in 2014 - 2015 years Cisdnieper Railway (PZ, a regional operator of the UZ) financed scientific researches for the purpose of improvement of an accounting system, distribution and a power consumption of a regenerated energy. Also propositions on implementation of ESS elements in $3.3 \mathrm{kV}$ DC power supply system and into electric locomotives were developed. The experimental part of the specified scientific researches is described in this paper.

\section{Choosing of experimental zone}

For the reasonable choice of the railway section for experimental researches the analysis of turnover on sections of Cisdnieper Railway (PZ) is carried out by our researcher's group (head of group - D. Sc., Professor Andrii Mukha). Results for 2013 (orange bars) and 2014 (grey bars) is presented in Fig. 1. It is easy to see that the maximum turnover is registered on the sections that situated between Nyzhn'odniprovs'k-Vuzol station and Chaplyne station. Thus the experimental zone has to be located in borders of these sections. Also experimental zone must have high track gradients for effective electric energy obtaining by using of regenerative braking mode.

In such a way we chose a zone for the experimental researches between traction substation "Rozdory" (№. 19) and traction substation "Pys'menna" (№. 20). Thus, the experiment area consists of four block sections with a total length of $17.8 \mathrm{~km}$. Chosen experimental zone has two tracks, which electrified by $3.3 \mathrm{kV}$ DC power supply system with two ways feeding and parallel connection of overhead catenary systems of both tracks.

Also during the experiments it was decided to use VL11M6 electric locomotives which have the modern integrated system of diagnostics and monitoring.

"Corresponding author: bondardiit@gmail.com 


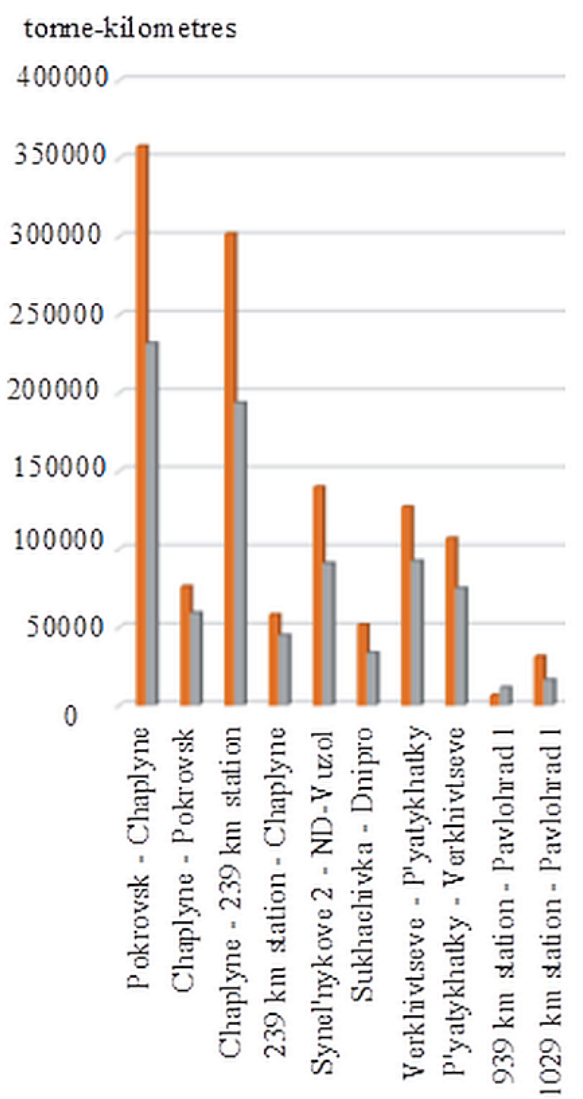

Fig. 1. Turnover at the most important sections of Cisdnieper Railway (PZ) in 2013 and 2014 years.

\section{Experimental researches: stage 1}

The purpose of the first stage of researches is experimental obtaining of time dependences of currents and voltages of traction substations and electric locomotives in the following modes: 1) "No-load mode"; 2) "Regenerative braking mode of electric locomotive", 3) "Regenerative braking mode of electric locomotive №1 and traction mode of electric locomotive №2”.

Measurements into the traction substations were executed with using of kits of measurement equipment. Two kits of measuring equipment were installed at the traction substations. Thus, four such kits were used in experimental studies. Each kit consists of the insulated platform, an autonomous power source which consists of a rechargeable battery and the inverter, additional resistance (for voltage reducing), digital USB oscilloscope and the laptop with the specialized software.

That equipment was placed into location of $3.3 \mathrm{kV}$ distributive devices of traction substations № 19 (see fig.2) and № 20 and connected to the electric traction network by the diagram which is presented in fig. 3 .

The connection of the measuring equipment was carried out after a voltage disconnection. According to the diagram in Figure 3, a digital oscilloscope was connected through channel $\mathrm{X}$ to the secondary terminals of the RS shunt using a high-voltage cable. At the same time, the $\mathrm{Y}$ channel of this oscilloscope is connected to the measuring terminals of the voltage divider. Primary terminals of this additional resistance are connected to the "_."'bus of $3.3 \mathrm{kV}$ distributive device. Thus, the common point $\mathrm{X}$ and $\mathrm{Y}$ channels of the oscilloscope have a potential of $3.3 \mathrm{kV}$ relative to the earth. This fact necessitates the placement of equipment on insulated platform. To prevent the possibility of electric shock to researchers, the location of the equipment was fenced and the control of measuring equipment was provided by remote control using a wireless mouse-type manipulator.

Registration of time dependences of voltage on the pantograph and current of each electric locomotive is executed with using of its onboard integrated systems of diagnostics and monitoring.

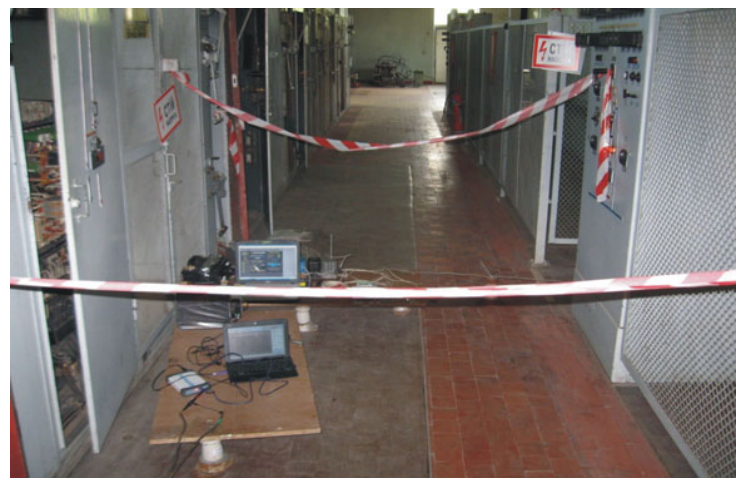

Fig. 2. Location of measurement equipment into the $3.3 \mathrm{kV}$ distributive device of traction substation № 19.

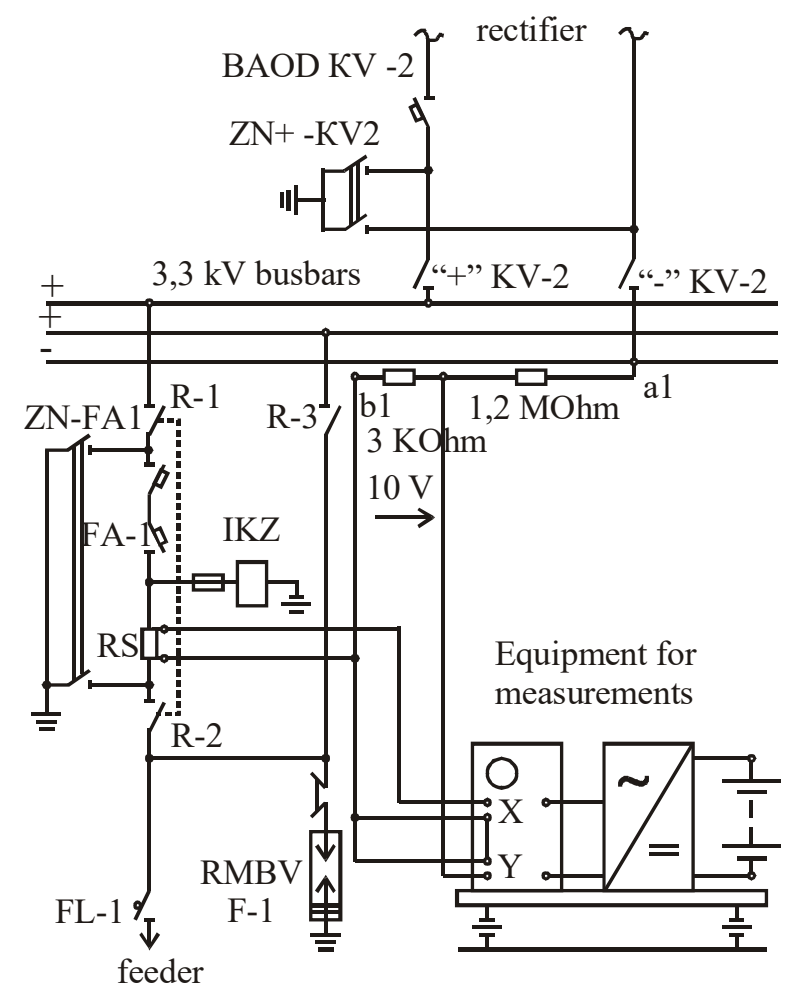

Fig. 3. Attaching diagram of measurement equipment for voltage and current registration.

In fig. 4 and fig. 5 an experimental time dependences of output voltage and FA 3 feeder current (traction substation №19) are presented. 


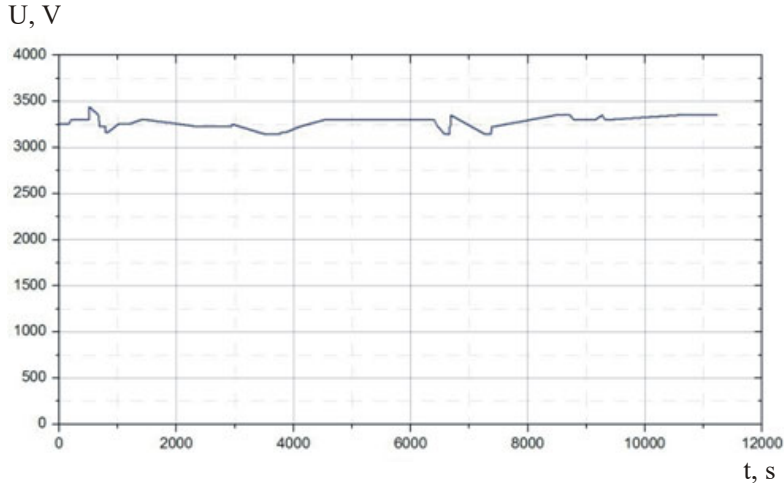

Fig. 4. Time dependence of output voltage of traction substation № 19 (after development).

From the theoretical point of view currents and voltages into the elements of the traction network are stochastic time functions. By statistical interpretation of the data, the laws of distribution of these random values are determined. In particular, it is defined, that voltage on the pantograph of an electric locomotive and its current in the mode of a regenerative braking can be described by the Gauss law. However the stochastic energy distribution of a regenerative braking $W_{R}$ is described by the log-normal law according to expression (1).

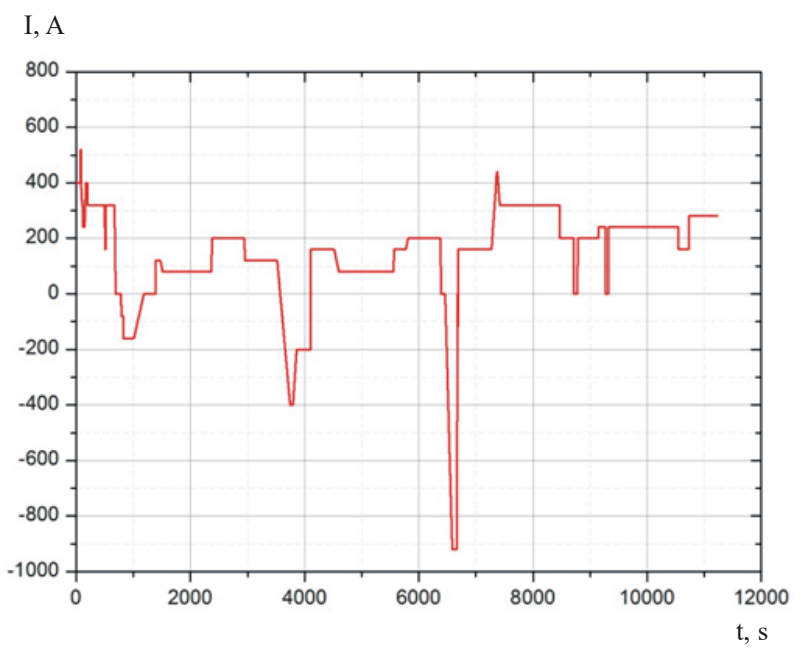

Fig. 5. Time dependence of FA 3 feeder current, traction substation № 19 (after development).

$$
f\left(W_{R}\right)=\frac{1}{W_{R} \cdot \sigma_{W_{R}} \cdot \sqrt{2 \cdot \pi}} \exp \left[-\frac{\left(\ln W_{R}-m_{W_{R}}\right)^{2}}{2 \cdot \sigma_{W_{R}}^{2}}\right],
$$

$m_{W_{R}}, \sigma_{W_{R}}$ - are the mean and standard deviation.

\section{Experimental researches: stage 2}

The first stage of an experiment lasted 3 hours and 15 minutes. As it is possible to see from fig. 5, during the experiment, we registered time intervals with negative values of the feeder current. This fact indicates the presence of regenerative braking energy flows outside the experimental zone to other parts of the traction network along which electric locomotives move in the power consumption mode.

It is necessary to avoid such phenomena during the second stage of an experiment for the purpose of obtaining correct balance of electric energy for the experimental section. Therefore the following changes were made to conditions of fulfilment of the second stage of the experimental researches.

1. The zone of an experiment is expanded from traction substation "Rozdory" (№. 19) to the sectioning post $3.3 \mathrm{kV}$ near Krasnoshchokove station. Total length of extended experimental zone $-47.6 \mathrm{~km}$.

2. During experiment time on the section movement only of electric locomotive No. 1 and No. 2 is alowed.

3. Track №1 in operation only. Electrical feeding of track №2 is switched off.

4. Experimental zone electrically disconnected from another feeding zones.

5. Registrated electirc values: consumed and regenerated electric energy; voltages and currents of electric locomotives (instantaneous values); electric locomotive speed.

6. Type of electric locomotives is VL11M6. Mass of train №1 4458 tons, mass of train №2 5022 tons.

Modes of movement of trains along the experimental zone are shown in Fig. 6 and Fig. 7.

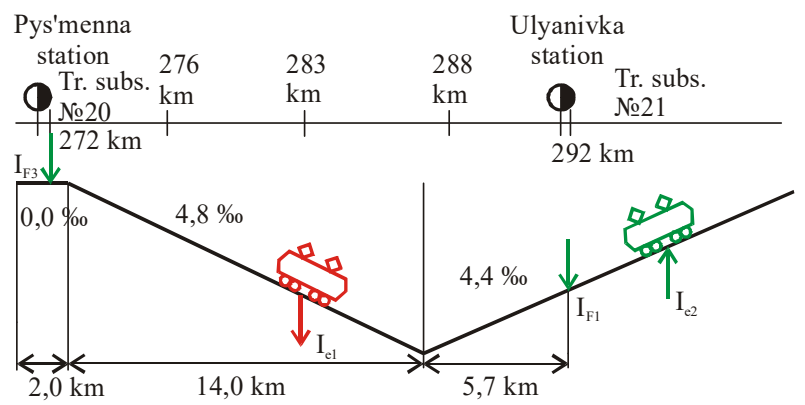

Fig. 6. Movement of trains along the experimental zone: traction mode of electric locomotive №1 and regenerative braking mode of electric locomotive №2.

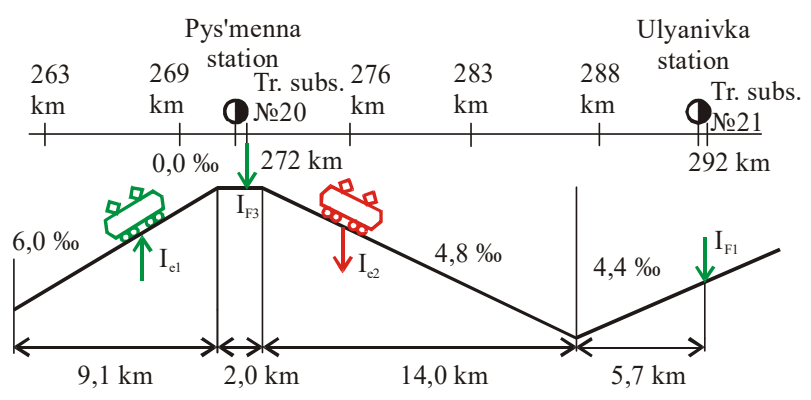

Fig. 7. Movement of trains along the experimental zone: regenerative braking mode of electric locomotive №1 and traction mode of electric locomotive №2.

As with the first stage of the experiment, the time dependences of the speeds, voltages, and currents of electric locomotives (Fig. 8-10) were obtained from the data of their built-in diagnostic and monitoring systems. These data made it possible to calculate the values of electrical energy that was consumed for train traction as 
well as the energy obtained by regenerative braking of electric locomotives №.1 and №.2 during the time of the experiment.

The results are presented in Table 1.

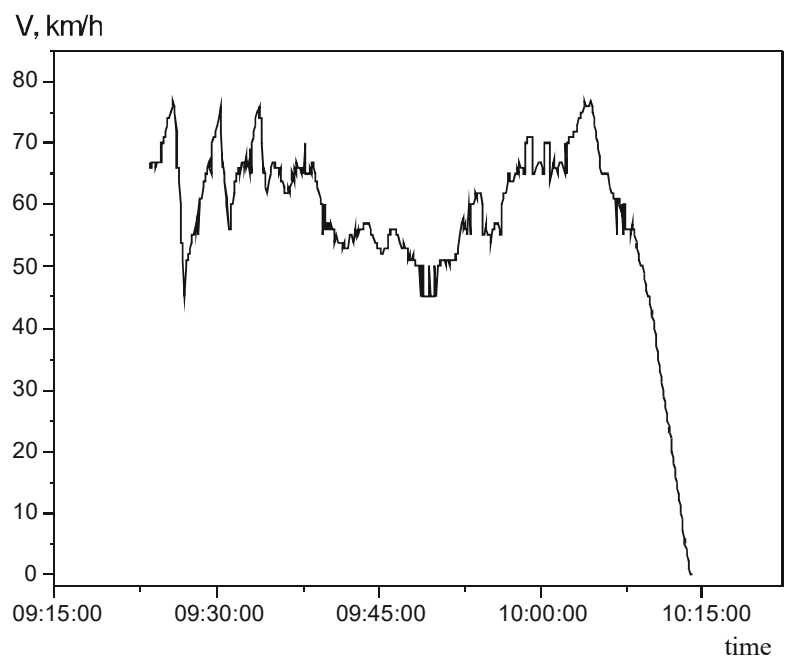

Fig. 8. Time dependence of train speed recorded from locomotive № 1 (experimental researches, stage 2).

Table 1. Consumed and regenerated energy of electric locomotives № 1 and №2.

\begin{tabular}{|c|c|c|}
\hline Indicator & $\begin{array}{c}\text { Electric } \\
\text { locomotive } \\
\text { № 1 }\end{array}$ & $\begin{array}{c}\text { Electric } \\
\text { locomotive } \\
\text { № 2 }\end{array}$ \\
\hline $\begin{array}{c}\text { Energy for traction } \\
\text { (according to the } \\
\text { electricity meters data), } \\
\text { kWh }\end{array}$ & 1790 & 2190 \\
\hline $\begin{array}{c}\text { Calculated electric } \\
\text { energy for traction, kWh }\end{array}$ & 1646 & 1558 \\
\hline $\begin{array}{c}\text { Difference between } \\
\text { experimental and } \\
\text { calculated values of } \\
\text { energy for traction, \% }\end{array}$ & +8.75 & +40.56 \\
\hline $\begin{array}{c}\text { Energy of regenerative } \\
\text { braking mode ((according } \\
\text { to the electricity meters } \\
\text { data), kWh }\end{array}$ & 350 & 290 \\
\hline $\begin{array}{c}\text { Calculated energy of } \\
\text { regenerative braking } \\
\text { mode, kWh }\end{array}$ & 392 & 335 \\
\hline $\begin{array}{c}\text { Difference between } \\
\text { experimental and } \\
\text { calculated values of } \\
\text { recovered energy, \% }\end{array}$ & -10.71 & -13.43 \\
\hline \multicolumn{2}{|c|}{. } & \\
\hline
\end{tabular}

According to the data from active electric energy meters of traction substations "Rozdory" (№19), "Pys'menna" (№20), "Ulyanivka” (№21), a temporary dependence of electric energy consumption was obtained during the experiment. The results are presented in Fig.11.

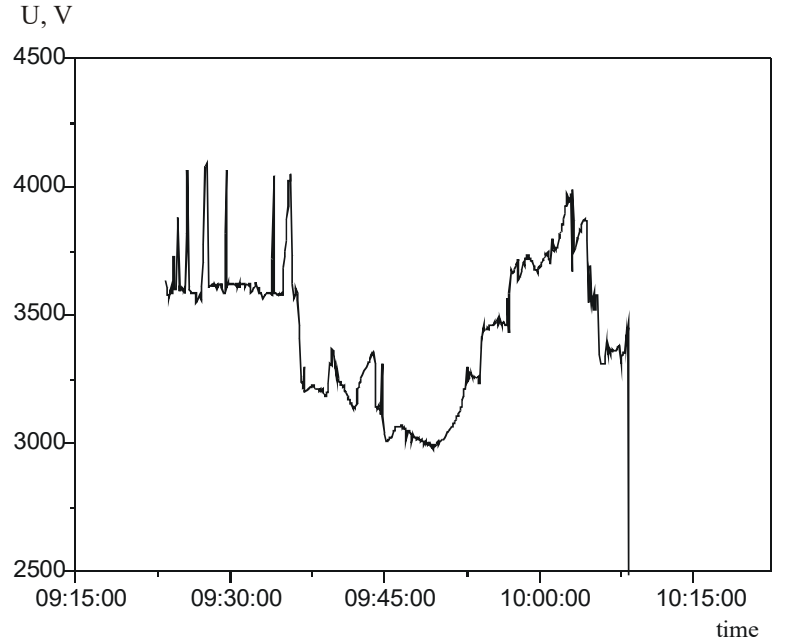

Fig. 9. Time dependence of pantograph voltage recorded from locomotive № 1 (experimental researches, stage 2).

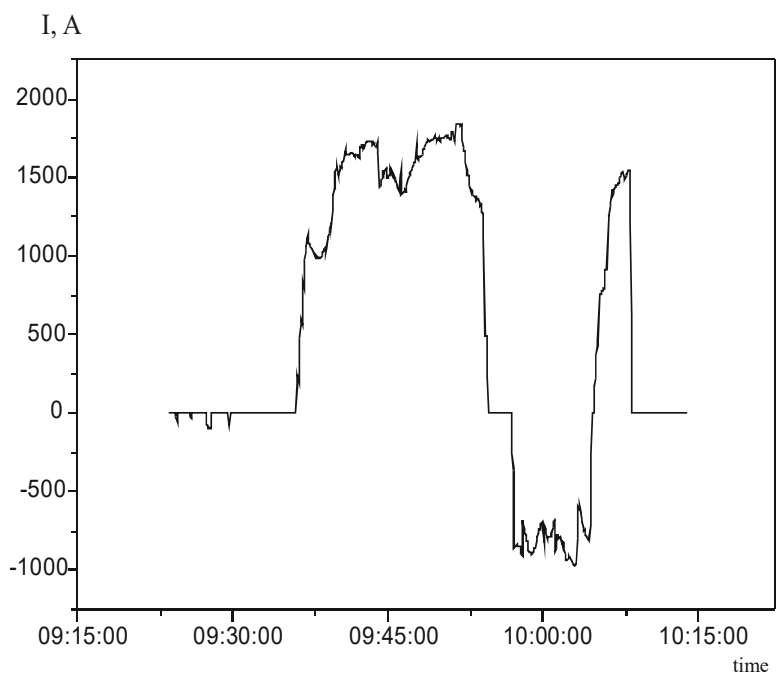

Fig. 10. Time dependence of current recorded from locomotive № 1 (experimental researches, stage 2).

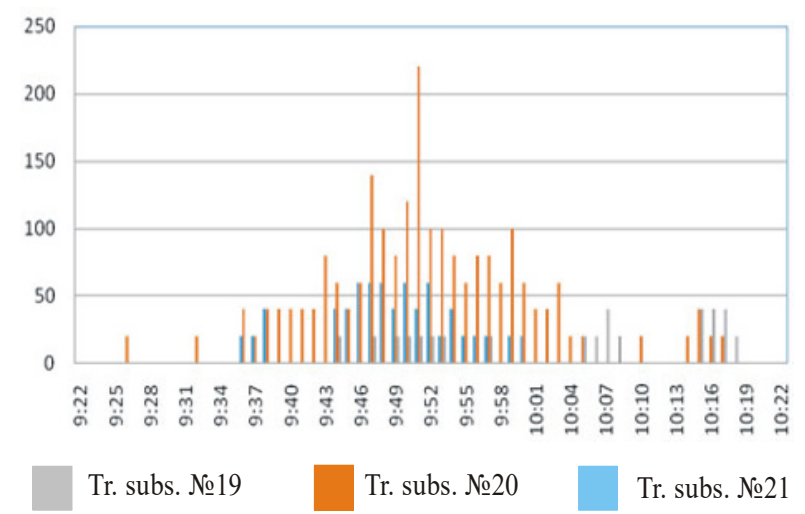

Fig. 11. Time dependence of electric energy consumption at the experimental zone (according to the electricity meters data).

This information makes it possible to determine the electrical energy transmitted by the traction substations to the electrical network of the experimental zone: $W_{S}=2784 \mathrm{kWh}$. 
Electric energy from regenerative braking mode of electric locomotives is $W_{R}=392+335=727 \mathrm{kWh}$ (see Table 1). Thus, the total energy of all electric power sources at the experimental zone during the experiment is

$$
W_{P S}=W_{S}+W_{R},
$$

$$
W_{P S}=2784+727=3511 \mathrm{kWh} \text {. }
$$

Electric energy losses in the traction network $\Delta W_{T}$ are calculated on the basis of experimental data based on the classical single-track model with two-way power supply [5] according to expression (2)

$$
\begin{gathered}
\Delta W_{T}=\frac{r \cdot 10^{3}}{T \cdot U^{2}} \cdot \sum_{k=1}^{n} \ell_{0 k}\left[1,08 T \cdot\left(1-\frac{\ell_{0 k}}{\ell}\right) \cdot \sum_{h=1}^{N} \frac{W_{k h}^{2}}{t_{k h д}}+\right. \\
\left.+2 W_{k t} \cdot \sum_{j=k+1}^{n} W_{j T}\left(1-\frac{\ell_{0 j}}{\ell}\right)\right]
\end{gathered}
$$

where $W_{k t}, W_{j T}$ - electric energy consumption by electric locomotives ;

$T$ - time for calculations;

$\ell-$ length between traction substations;

$\ell_{0 k}, \ell_{0 j}$ - distances from the traction substation to the middle of the sections $k$ and $j$;

$U$ - voltage of the traction network;

$r$ - resistance of $1 \mathrm{~km}$ of traction network.

The results of the calculations show that the electric power losses in the traction network from the currents of the traction substations $\Delta W_{T}$ amounted to $149.1 \mathrm{kWh}$ (approximately 5\% of the energy supplied by the traction substations). At the same time, the regenerative braking energy losses in the traction network between electric locomotives $\Delta W_{R}$ reached $98 \mathrm{kWh}(13.4 \%$ of the recovered energy).

Based on the obtained values, the divergence of the electric energy balance of the experimental zone can be calculated by the formula

$$
\delta W=W_{P S}-W_{L 1}-W_{L 2}-\Delta W_{T}-\Delta W_{R},
$$

where $W_{L 1}, W_{L 2}$ - electric energy consumed for traction by electric locomotives.

This divergence is $\delta W=59.9 \mathrm{kWh}$ or $1.7 \%$ of the energy of power sources. However, if we use the data of electric power meters of electric locomotives when calculating this value, we will get the value of $803.1 \mathrm{kWh}(23.45 \%$ of the energy of power sources), which significantly exceeds the generally accepted norms and assumptions.

\section{Location of ESS equipment: variants and proposals}

There are two strategies for placing of ESS equipment with supercapacitors that is designed to store regenerative braking energy [2]. The first strategy (stationary ESS) is to arrange the ESS equipment at the traction substations (substation-inside ESS) or other elements of the traction power supply system (wayside ESS). Several literatures deal with the problems of implementations of the stationary ESS systems into DC traction power supply system of metro lines [2-3] and railway lines [6-9].

We suppose that in the system of traction power supply of Ukrainian railways $(3.3 \mathrm{kV})$ for sections with heavy traffic can be used stationary ESS containing wayside and substation-inside elements. However, the development and implementation of this system requires large investments as well as a significant amount of scientific research. In this case, implementation of the ESS system is only an integral part of measures for improvement the energy efficiency of the traction power supply system. Therefore, when choosing the location and capacity of ESS system elements, it is necessary to take into account the possibility of implementation other innovations, for example, using distributed solar electricity generators to improve the voltage mode in the traction network. [10].

The second strategy involves placing the ESS equipment directly on the locomotive (on-board ESS) [4]. This option is advisable to use if the purpose of implementation an ESS is primarily the efficient use of regenerative braking energy. It is rational to take the capacity of the on-board ESS based on the most probable value of electric power (probability $0.94 \ldots$ 0.95) obtained in the process of regenerative braking. In turn, this value can be obtained by the method of stochastic analysis [11-13] using the data obtained during the experimental studies described in this paper.

A detailed comparison of both strategies for ESS storage by energy efficiency criteria is described in [14]. The results of calculation for various varieties of ESS are presented in tables 2 and 3.

Table 2. Calculation results for using substation-inside ESS (according to [14]).

\begin{tabular}{|c|c|c|c|}
\hline Indicator & $\begin{array}{c}\text { Traction } \\
\text { substation } \\
\text { without } \\
\text { stationary } \\
\text { ESS }\end{array}$ & $\begin{array}{c}\text { Traction } \\
\text { substation } \\
\text { with } \\
\text { stationary } \\
\text { ESS }\end{array}$ & $\begin{array}{c}\text { Difference, } \\
\%\end{array}$ \\
\hline $\begin{array}{c}\text { Electric energy } \\
\text { consumption, kWh }\end{array}$ & 100 & 93.6 & -6.4 \\
\hline $\begin{array}{c}\text { Electric energy loses } \\
\text { into the traction } \\
\text { network, \% }\end{array}$ & 3.5 & 3.6 & +0.1 \\
\hline \begin{tabular}{c} 
Minimum voltage, V \\
\hline $\begin{array}{c}\text { Load factor of the } \\
\text { main step-down } \\
\text { transformer }\end{array}$
\end{tabular} & 3017 & 3052 & +1.2 \\
\hline $\begin{array}{c}\text { Load factor of the } \\
\text { traction transformer }\end{array}$ & 0.16 & 0.15 & -6.2 \\
\hline $\begin{array}{c}\text { Section bandwidth } \\
\text { (even / odd direction), } \\
\%\end{array}$ & 100 & 100 & - \\
\hline $\begin{array}{c}\text { Minimum interval, } \\
\text { min }\end{array}$ & 12 & 12 & - \\
\hline
\end{tabular}


Table 3. Calculation results for using on-board ESS (according to [14]).

\begin{tabular}{|c|c|c|c|}
\hline Indicator & $\begin{array}{c}\text { Electric } \\
\text { locomotive } \\
\text { without on- } \\
\text { board ESS }\end{array}$ & $\begin{array}{c}\text { Electric } \\
\text { locomotive } \\
\text { with on- } \\
\text { board ESS }\end{array}$ & $\begin{array}{c}\text { Difference, } \\
\%\end{array}$ \\
\hline $\begin{array}{c}\text { Electric energy } \\
\text { consumption, kWh }\end{array}$ & 100 & 81.1 & -12.9 \\
\hline $\begin{array}{c}\text { Electric energy loses } \\
\text { into the traction } \\
\text { network, \% }\end{array}$ & 6.5 & 1.9 & -4.6 \\
\hline $\begin{array}{c}\text { Minimum voltage, V } \\
\text { Load factor of the } \\
\text { main step-down } \\
\text { transformer }\end{array}$ & 1.39 & 0.49 & -64.7 \\
\hline $\begin{array}{c}\text { Load factor of the } \\
\text { traction transformer }\end{array}$ & 0.9 & 0.28 & -68.9 \\
\hline $\begin{array}{c}\text { Section bandwidth } \\
\text { (even / odd direction), } \\
\%\end{array}$ & 100 & 150.5 & +50.5 \\
\hline $\begin{array}{c}\text { Minimum interval, } \\
\text { min }\end{array}$ & 12 & 8 & -33.3 \\
\hline
\end{tabular}

Our own further calculations also showed that the use of the onboard ESS can significantly improve the efficiency of the traction power supply system. Electricity consumption for electric traction can be reduced by $18.9 \%$. At the same time, the total losses in the transmission of electric energy are reduced by $12 \%$. Also, the load of transformers and rectifiers at traction substations is significantly reduced.

\section{Conclusions}

As a result of the research we can draw the following conclusions.

1. It was experimentally confirmed that in the normal mode of operation of the experimental section, regenerative braking of an electric locomotive can occur when it is significantly removed from the electric locomotive in traction mode (distance of $20 \mathrm{~km}$ or even more). In this case, a substantial part of the regenerated energy is expended on heating the elements of the traction network.

2. Despite the fact that VL11M electric locomotive traction motors are DC electric machines, they are able to generate alternating low frequency voltages and currents $(f=0.01 \ldots 9 \mathrm{~Hz})$ into the traction network during regenerative braking of the electric locomotive, which are also stochastic values. In this case, in the experimental section, the voltage on the pantograph of an electric locomotive varies from 3102 to $3965 \mathrm{~V}$ and the regenerative braking current varies from 50 to 1734 A.

3. The value of electrical energy calculated by the results of monitoring (not according to the indications of electric power meters of the electric locomotives), which is recovered by an electric locomotive VL11M6, during one trip ranges from 807 to $1118.8 \mathrm{kWh}$. In this case, during one trip we observed $11 \ldots 16$ phases of regenerative braking with different duration. At each of these phases, the value of the recovered energy varies from 0.5 to $172 \mathrm{kWh}$.

4. Accounting for electric energy, which is consumed for traction of electric locomotives used in the experiment is unsatisfactory. The divergence between the calculated values and registered values by electric energy meters SKVT-D261 type can reach $40 \%$. At the same time, the adequacy of the calculated values is verified by comparing with the data of high-precision electronic electric energy meters ABB EA05RL-P2C-3 type that are installed at the traction substations (divergence less than 1.7\%).

5. Accounting of regenerated energy on electric locomotives used in the experiment is also unsatisfactory. The divergence between the data of the SKVT-D261 type electric energy meters and the experimentally determined values of the recovered energy can reach $13 \%$. It is advisable to use meters with a higher accuracy class on electric locomotives.

6. We suppose that it is most expedient to accumulate the recovered energy directly on the electric locomotive using the electric energy storage system based on supercapacitors. Define of the rational parameters of ESS can be performed using stochastic analysis based on the time dependencies of the currents and voltages of electric locomotives that we obtained in the regenerative braking mode.

Finally we consider that implementation of using of ESS equipment is only s part of an integrated approach to the modernization of Ukrainian electric locomotives. Our research team also fulfils studies in areas of improvement the characteristics of pantograph contact inserts, the development of galvanic restoration technologies worn-out large-size details of the rolling stock, as well as the development and modelling of traction transformers for modern Ukrainian electric locomotives for the $27.5 \mathrm{kV} \mathrm{AC}$ electric power supply system.

\section{References}

1. A. Mukha, M. Kostin, O. Bondar, A. Nikitenko, O. Kurylenko, Prerequsities of execution the experimental studies for definition of current state of using and accounting of the electrical rolling stock's regenerative energy on section of the "Pridniprovska" railway, Electrification of Transport, Dnipropetrovsk, Ukraine, № 13, pp. 5458, (2017) [in Ukrainian]

2. B. Wang, Zh. Yang, F. Lin, W. Zhao, An Improved Genetic Algorithm for Optimal Stationary Energy Storage System Locating and Sizing, Energies, Basel, Switzerland, 7(10), pp. 6434-6458, (2014)

3. H. Xia, H. Chen, Zh. Yang, F. Lin, B. Wang, Optimal Energy Management, Location and Size for Stationary Energy Storage System in a Metro Line Based on Genetic Algorithm, Energies, Basel, Switzerland, 8(10), pp. 11618-11640, (2015) 
4. Y. Geng, B. Li, Zh Yang, F. Lin, H. Sun, A High Efficiency Charging Strategy for a Supercapacitor Using a Wireless Power Transfer System Based on Inductor/Capacitor/Capacitor (LCC) Compensation Topology, Energies, Basel, Switzerland, 10(1), 135 pp. 1-17 (2017)

5. K. G. Markvardt, Power supply of electrified railways, Pub. "Transport", Moscow, (1982) [in Russian]

6. T. Ratniyomchai, S. Hillmansen, P. Tricoli, Optimal Capacity and Positioning of Stationary Supercapacitors for Light Rail Vehicle Systems, International Symposium on Power Electronics, Electrical Drives, Automation and Motion, IEEE, 807-812 (2014).

7. P. V. Radu, and Z. Drabek, "Analysis of wayside energy storage devices for DC heavy rail transport", Proceedings of 13th International Conference "Modern Electrified Transport" MET'2017, Warsaw, Poland, Vol. 180, 04001 (2018)

8. A. Szelag, T. Maciolek, Z. Drazek, M. Lewandowski, Conditions for the effective use of traction substations with possible return of trains regenerative braking energy into a power network in a $3 \mathrm{kV} \mathrm{DC}$ supply system, Logistyka 3, pp. 46834692 (2015)

9. W. Jefimowski, and A. Nikitenko, "Case study of stationary energy storage device in a $3 \mathrm{kV}$ DC traction system", Proceedings of 13th International Conference "Modern Electrified Transport"
MET'2017, Warsaw, Poland, Vol. 180, 02005 (2018)

10. V. G. Sychenko, D. O. Bosiy, E. M. Kosarev , Improving the quality of voltage in the system of traction power supply of direct current, Archives of Transport, Warsaw, Poland, Vol. 35, Iss. 3, pp. 6370 (2015)

11. M. Kostin, The methods for powers determination in the systems withstochastic electric processes, Technical Electrodynamics, Kyiv, Ukraine, , vol. 6, pp. 6-8 (2006)

12. M. Kostin, A. Nikitenko, Statistics and Probability Analysis of Voltage on the Pantograph of DC Electric Locomotive in the Recuperation Mode, Przegląd Electrotechniczny, Warsaw, Poland, No 2a, pp. 273-275 (2013)

13. A. Nikitenko, M. Kostin, The method of the correlation and dispersion defining of the total power components in the electric transport devices, Science and Transport Progress. Bulletin of Dnipropetrovsk National University of Railway Transport, Dnipropetrovsk, Ukraine, vol. 1(44), pp. 64-75 (2013)

14. V.T. Cheremisin, M. M. Nikiforov, V . L. Nevezak, The choice of placement of equipment for energy storage at the DC experimental section according to the criterion of energy efficiency, Science and transport, St. Petersburg, Russia, 2(6), pp. 48-52 (2013) 